\title{
GELEŽIES STOKOS ANEMIJA KŪDIKIAMS, VAIKAMS IR PAAUGLIAMS: RIZIKOS VEIKSNIAI IR JU巳 PREVENCIJA
}

\author{
Vykinta Zeleckytė, Martynas Zaremba, Valdonė Ališkevičiūtė \\ Lietuvos sveikatos moksly universitetas, Medicinos akademija, Medicinos fakultetas
}

Raktažodžiai: geležies stokos anemija, kūdikiai, vaikai, paaugliai.

\section{Santrauka}

Geležies stokos anemija (mažakraujystè) yra patologinè būklè, dažnai pasireiškianti kūdikiams, vaikams ir paaugliams. Didesnè rizika susirgti vaikams aiškinama didesniu geležies poreikiu dèl spartaus augimo, padidejjus lieso kūno masei, raudonujų ląstelių masei ir kraujo kiekiui, dèl kurių didèja geležies poreikis hemoglobino kiekiui kraujyje bei mioglobino kiekiui raumenyse. Straipsnyje išanalizuotos mokslinės publikacijos, kuriose aprašyti dažniausiai pasitaikantys rizikos veiksniai, sukeliantys geležies stokos anemiją. Nustatyta, kad kūdikiams ši liga dažniausiai pasireiškia dẻl motinos geležies stokos anemijos néštumo metu ar ankstyvo virkštelès užspaudimo po gimimo. Vaikams ir paaugliams - dèl per mažo geležies gavimo su maistu, antsvorio ar nutukimo, menarchès (pirmujų menstruacijų) ar kitų menstruacinio ciklo sutrikimų mergaitėms. Rasta publikacijų, įrodančių, kad šios ligos pasireiškimo galima išvengti imantis atitinkamų prevencijos veiksmų. Apibendrinus rezultatus, padarytos išvados, jog geležies papildų vartojimas néštumo metu padidina hemoglobino koncentraciją kraujyje ir žymiai sumažina naujagimių anemijos riziką, geležies deficitą ir mažo svorio naujagimio riziką. Pavèlintas virkštelès užspaudimas ( $>3$ minutes) turi reikšmingą poveikị naujagimių geležies kiekiui ir turi ịtakos geležies stokos anemijos pasireiškimui naujagimiams iki 4 mėnesių. İvertinus tyrimus pastebėta, kad neišnešiotiems naujagimiams svarbu gauti papildomos geležies preparatų. Esant mitybos sutrikimų, svarbu paaiškinti, kad geležies, gaunamos iš mèsos (raudonos arba baltos), biologinis prieinamumas yra didesnis. Be mèsos, vaikai turètụ būti skatinami valgyti citrinas, daržoves ir ankštinius augalus, ispejjami vengti sodos, arbatos, kavos, per didelio pieno kiekio ir javu, kurie mažina geležies absorbciją. Rasta publikacijų, kad pirminé geležies stokos prevencija ge- ležies preparatais paaugliams nerekomenduojama, išskyrus atvejus, kai pasireiškia kiti sutrikimai, pvz., gausus menstruacinis ciklas.

\section{Ivadas}

Geležies stokos anemija yra viena iš dažniausiai pasitaikančių visuomenès sveikatos problemų. Anemija apibūdinama kaip patologinis procesas, kurio metu eritrocitu hemoglobinas (Hb), hematokritas $(\mathrm{Ht})$ ir raudonujų kraujo kūnelių koncentracija tūrio vienete yra neịprastai maža, palyginti su referencinès populiacijos periferinio kraujo parametrais [2]. Anemija vaikams apibrèžiama kaip hemoglobino lygis, kuris yra dviem standartiniais nuokrypiais žemiau amžiaus vidurkio [3-4]. Ja serga iki 50 proc. jaunesnių nei 5 metų vaikų [1]. Vaikams sulaukus 12 metų, hemoglobino normą galima suskirstyti ị lytims būdingus intervalus [4]. Anemija gali būti klasifikuojama kaip mikrocitinè, normocitinè ar makrocitinè. Mikrocitinè geležies stokos anemija dažniausia vaikystejje, o makrocitinè anemija vaikams nustatoma retai [5]. Geležies poreikis jaunesniame amžiuje yra labai didelis dèl spartaus augimo, padidejus lieso kūno masei, raudonųjų ląstelių masei ir kraujo kiekiui. Dèl to dideja geležies poreikis hemoglobino kiekiui kraujyje bei mioglobino kiekiui raumenyse. Nepavykus patenkinti didelio geležies poreikio, atsiranda geležies stokos anemija. Didelis geležies vartojimas gali sukelti sveikatos problemų. Vaikams, turintiems genetini polinkị absorbuoti daugiau geležies nei ịprasta, geležis kūno audiniuose gali kauptis daug dešimtmečių, o tai gali pažeisti audinius ir organus [6]. Anemijos pasekmès mokyklinio amžiaus vaikams yra sutrikusi psichomotoriné raida bei intelekto koeficientas, neigiamas ilgalaikis poveikis centrinei nervų sistemai, blogi mokymosi rezultatai, sumažejęs darbingumas ir prasta gyvenimo kokybe [7].

Pasaulio sveikatos organizacijos (PSO) duomenimis, nuo 45,7 iki 49,1 proc. mokyklinio amžiaus vaikų serga anemija [8]. PSO praneša, kad bendras kūdikių ir vaikų (nuo 6 iki 59 mènesiu) sergamumas anemija Jungtinèse Amerikos Valstijose (JAV) 2011 metais buvo žemas - 6 procentai [9]. Išimtis 
- nepasiturinčių šeimų vaikai. Federaliniu būdu finansuotų programų, vertinusių nepasiturinčių šeimų vaikų sveikatos būklę, dešimties metų (2001-2010 m.) duomenys parodè, kad anemijos paplitimas šioje populiacijoje padidejo nuo 13,4 iki 14,6 procento. Didžiausias nustatytas 12-17 mènesių vaikų sergamumas $-18,2$ procento [10]. Šiame straipsnyje aptariami geležies stokos anemijos kūdikiams ir vaikams rizikos veiksniai bei jų prevencija.

Tyrimo tikslas - apžvelgti prieinamą mokslinę literatūrą ir aptarti pagrindinius geležies stokos anemijos rizikos veiksnius, pasitaikančius naujagimystèje, vaikystejje ir paauglysteje bei jų prevenciją.

\section{Tyrimo medžiaga ir metodai}

Mokslinių straipsnių paieška vykdyta PubMed, UpToDate, Medscape duomenų bazèse. I literatūros apžvalgą itraukti anglų kalba 2010-2020 m. publikuoti atsitiktinių imčių kontroliuojami tyrimai, originalūs stebejjimo tyrimai, atvejų ataskaitos, atvejų serijos ir apžvalgos. Straipsnyje pateikiami mokslinių leidinių analizès rezultatai.

\section{Tyrimo rezultatai}

Geležies metabolizmas. Geležis yra vienas svarbiausių komponentų medžiagų apykaitos procese, kuris perneša deguonị i audinius. Vidutiniškai žmogaus organizme yra $3-5 \mathrm{~g}$ geležies $(\mathrm{Fe})$. Standartinès dietos metu (normaliai maitinantis) gaunamos geležies kiekis yra $15 \mathrm{mg}$. Rūgšti aplinka padeda absorbuoti geleži pirmojoje ir antrojoje plonosios žarnos dalyse, todèl geležies absorbcija intensyvejja kartu vartojant rūgštinius preparatus, tokius kaip askorbo rūgštis. Geležies absorbcija natūraliai pradeda didèti, kai padidèja jos poreikis. Po absorbcijos, baltymų surišta geležis pernešama ị kaulų čiulpus ir ịtraukiama ị raudonųjų kraujo kūnelių gamybą [11]. Geležies perteklius saugomas feritino pavidalu, kuris yra labilus bei greitai prieinamas geležies tiekejjas [12]. Gimusiems sveikiems, laiku ir normalaus svorio kūdikiams Fe atsargų užtenka iki 6 mènesių [13]. Geležies stokos anemija atsiranda, kai sutrinka geležies suvartojimo ir organizmo geležies atsargų bei jų suvartojimo pusiausvyra, reikalinga palaikyti normalią eritrocitų gamybą [14]. Neišnešiotiems naujagimiams Fe stoka gali prasidèti nuo 2-3 gyvenimo mènesio [15]. Normalūs hemoglobino lygio kiekiai, atsižvelgiant ị vaiko amžių, pateikiami 1 lentelèje [16].

Rizikos veiksniai. Europoje dažniausi kūdikių ir vaikų geležies stokos anemijos rizikos veiksniai yra motinos geležies stokos anemija, ankstyvas virkštelès užspaudimas [17] per mažas geležies gavimas su maistu, antsvoris ir nutukimas bei menarchè ir menstruacinio ciklo sutrikimai [2].

Motinos geležies stokos anemija. Manoma, kad nèštumo metu (nuo pastojimo iki gimdymo) reikalingas geležies kie- kis yra 1200 mg [18]. Geležies suvartojimas ir atsargos nèštumo metu turi būti pakankamos, kad patenkintų normalų vaisiaus vystymąsi bei kraujo netekimą gimdymo metu. Motinos geležies stokos anemija néštumo metu ir perinataliniu laikotarpiu turi neigiamą poveikį tiek motinai, tiek vaikui. Kartu su ịprastais anemijos simptomais vaikui gali pasireiškti kognityviniai defektai bei sumažèti vaisiaus smegenų brendimas [19]. Svarbu paminėti, kad negydoma motinos geležies stokos anemija gali būti perduodama naujagimiui. Negydyta geležies stokos anemija kūdikiams, vaikams ar paaugliams bei su geležimi susiję kognityviniai defektai gali būti perduoti ateities kartoms, panašiai kaip genetiniai bruožai. Jei šis trūkumas nebus išgydytas tam tikrame gyvenimo etape, nenutrūkstamas ciklas gali būti perduodamas iš kartos ị kartą daugelị metų [14].

Ankstyvas virkštelès užspaudimas. Virkštelès užspaudimo laikas turi didelę reikšmę kraujo kiekiui, patekusiam iš placentos naujagimiui, todèl gali turèti ịtakos vẻlesniam geležies stokos anemijos išsivystymui. Pavèlintas virkštelès užspaudimas (maždaug nuo 120 iki 180 sekundžių po gimdymo) yra susijęs su padidèjusiu geležies kiekiu (feritino lygiu) vaikams nuo 2 iki 6 mènesių. Tai ypač svarbu tiems, kurie jautrūs geležies trūkumui, pvz.: neišnešiotiems, ar mažo svorio naujagimiams [20].

Per mažas geležies gavimas su maistu. Literatūroje paminèta daugybė mitybos ypatumų, lemiančių geležies stokos anemiją kūdikiams ir vaikams. Dažniausias kūdikystèje ankstyvas žindymo nutraukimas. Su motinos pienu naujagimis gauna tokių maisto medžiagų kaip geležis, folio rūgštis, vitaminas A, vitaminas B12 ir kt., todèl anksti nutraukus maitinimą motinos pienu dideja anemijos rizika. Dauginis mikroelementų vaikams trūkumas plačiai paplitęs pasaulyje, gali pasireikšti bet kurio amžiaus vaikui, sutrikdyti jo fizinę ir pažintinių funkcijų raidą [2]. Vaikystejje mityba ypač svarbi dèl šiuo laikotarpiu padidejjusio maisto medžiagu poreikio augimui ir vystymuisi, todèl gyvybiškai svarbu, kad vaiko

1 lentelè. Normalus hemoglobino kiekis pagal vaiko amžių

\begin{tabular}{|l|c|}
\hline Amžius & Hg kiekis $(\mathbf{g} / \mathbf{l})$ \\
\hline Naujagimis & 165 \\
\hline 1 mėnuo & 139 \\
\hline 2 mėnesiai & 112 \\
\hline $3-6$ mènesiai & 115 \\
\hline 6 mėnesiai - 2 metai & 120 \\
\hline $2-6$ metai & 125 \\
\hline $6-12$ metų & 135 \\
\hline $12-18$ metų & $145-$ berniukams \\
& $140-$ mergaitèms \\
\hline
\end{tabular}


mityboje būtų reikiamas geležies kiekis, kurio biologinis prieinamumas būtų pakankamas šiems kūno poreikiams patenkinti. Geležies poreikis dideja dèl intensyvaus augimo bei raumenų vystymosi, todèl padideja ir kraujo tūris. Vaikysteje geležies suvartojimas gali būti nepakankamas dẻl keliu priežasčių: nepakankama mityba kūdikysteje (ankstyvas žindymo nutraukimas), valgymo sutrikimai (anoreksija, bulimija), nepakankamas geležies kiekis maiste (greitomaisčio vartojimas), vegetarizmas ir kt. [21].

Antsvoris ir nutukimas. Antsvoris ar nutukimas vis dažniau nustatomas vaikams ir paaugliams. Jų geležies trūkumas gali būti susijęs su nedaug mikroelementų, daug kalorijų turinčia dieta, didesniu geležies poreikiu, susijusiu su kūno svoriu, genetine predispozicija ir (arba) mažu fiziniu aktyvumu $[22,23]$. Be to, antsvoris ir nutukimas sukelia nenutrūkstamą uždegiminį procesą, kuris sustiprina anemijos pasireiškimą ir trukdo gydymui [24].

Menarche ir menstruacinio ciklo sutrikimai kartu su netinkama mityba. Gausus menstruacinis kraujavimas yra dažna mergaičių geležies stokos ir geležies stokos anemijos priežastis. Šiais atvejais menstruacinis kraujavimas būna vidutinio gausumo, tačiau ilgesnis nei ịprasta, todèl atsiranda neigiama geležies pusiausvyra $[25,26]$. Geležies stokos anemija paaugliams berniukams pasireiškia rečiau nei mergaitems. Tai paaiškinama fiziologiniu hemoglobino kiekio padidejimu, kurị sukelia lytinis brendimas. Nepaisant to, geležies trūkumas šioje amžiaus grupejje gali būti didesnis dèl kraujo tūrio ir raumenų masès padidejimo [27]. Kita vertus, bet kokị hemoglobino kiekio padidejjimą, kurio gali tikètis mergaitès, kompensuoja mènesinių kraujo netekimas $[28,29]$. Kiti veiksniai, galintys padidinti mergaičių geležies stokos anemijos riziką, yra intrauterinès spiralès naudojimas, nèštumas ir gimdymas [30, 31].

2 lentelè. Rekomeduojamas papildomas geležies suvartojimo kiekis vaikams

\begin{tabular}{|l|l|}
\hline Amžius & Papildomas geležies kiekis \\
\hline $\begin{array}{l}\text { Neišnešioti (<37 ges- } \\
\text { tacinės savaitės) nau- } \\
\text { jagimiai: nuo 1 iki } 12 \mathrm{mg} / \mathrm{kg} \text { kūno svorio per parą, jei mai- } \\
\text { tinamas tik krūtimi } \\
\text { mẻnesių }\end{array}$ & $\begin{array}{l}\text { mg/kg per parą, jei taikoma geležimi } \\
\text { papildyta formulè }\end{array}$ \\
\hline $\begin{array}{l}\text { Išnešioti naujagimiai: } \\
\text { nuo 4-6 iki } 12 \text { mènesių }\end{array}$ & $\begin{array}{l}1 \mathrm{mg} / \mathrm{kg} \text { kūno svorio per parą, jei mai- } \\
\text { tinamas tik krūtimi } \\
\text { Papildai nereikalingi, jei taikoma gele- } \\
\text { žimi papildyta formule }\end{array}$ \\
\hline $1-3$ metai & $\begin{array}{l}7 \mathrm{mg} \text { per parą; keisti dietą ir (arba) pa- } \\
\text { pildą, jei nustatyta anemija }\end{array}$ \\
\hline $4-8$ metai & $\begin{array}{l}10 \mathrm{mg} \text { per parą; keisti dietą ir (arba) } \\
\text { papildą, jei nustatyta anemija }\end{array}$ \\
\hline
\end{tabular}

\section{Prevencija}

Geležies vartojimas néštumo metu. Pasaulyje iki 42 proc. něščiujų serga anemija [1]. Kiekvieną něštumo trimestrą geležies poreikis didejja, todèl jis turètų būti palaikomas suvartojant didesnị geležies kiekị [32]. PSO rekomenduojamas geležies kiekis něštumo metu sudaro $60 \mathrm{mg}$ geležies kasdien. B. Haider ir kt. 2013 metais atliktoje sistemineje literatūros apžvalgoje nustatyta, kad 48 randomizuotuose tyrimuose (17 793 moterų) ir 44 kohortinèse studijose buvo nustatyta, kad geležies papildų vartojimas padidino hemoglobino koncentraciją iki 4,59 g/l lyginant su kontroline grupe ir žymiai sumažino anemijos riziką, geležies deficitą, anemijos dèl geležies stokos ir mažo svorio naujagimio riziką. Šis tyrimas parodè, kad padidinus geležies kiekị bent $10 \mathrm{mg}$ per dieną (iš viso iki $66 \mathrm{mg}$ per dieną) 12 proc. sumažèja anemijos, 3 proc. mažo svorio naujagimio rizika, o naujagimio svoris padideja 15,1 gramo. Padidinus hemoglobino kiekị kraujyje $1 \mathrm{~g} / \mathrm{l}$, vaisiaus svoris padidejja 14 gramų [33].

Pavèlintas virkštelès užspaudimas. Kitas būdas išvengti naujagimių anemijos yra pavèlintas naujagimio virkštelès užspaudimas [14]. Andersonas ir kt. 2011 metais atsitiktinių imčių tyrime ištyre 400 išnešiotų naujagimių. Vienų virkštelè buvo užspausta anksti ( $<10$ sekundžių), kitiems pavèluotai ( $>3$ minutes). Šis tyrimas parodè reikšmingą poveikị naujagimių geležies kiekiui bei reikšmingai proporcingą geležies stokos pasireiškimą iki 4 ménesių naujagimiams (anemija pasireiškè 5,7 proc. kūdikių iki 4 mėnesių, kuriems virkštelè buvo užspausta anksti ir 0,6 proc., kuriems buvo užspausta pavèluotai). Nè vienam iš kūdikių, kuriems buvo uždelstas (3 min.) virkštelès užspaudimas, feritino koncentracija nebuvo mažesnè nei $20 \mathrm{mg} / \mathrm{l}$, palyginti su sumažejusiu feritino kiekiu 7,4 proc. tiriamųjų, kuris buvo užfiksuotas užspaudžiant virkštelę beveik iškart po gimdymo [20].

Mityba. Geležis yra dažniausiai pasitaikanti maisto medžiaga, kurios trūksta mityboje. Neišnešioti naujagimiai (gimę anksčiau nei 37 něštumo savaitę), maitinami tik krūtimi, nuo 1 iki 12 mènesių amžiaus turètų gauti $2 \mathrm{mg} / \mathrm{kg}$ geležies papildo per parą [3], išskyrus tuos, kuriems buvo daug kartų perpilta kraujo. Sveikiems, išnešiotiems naujagimiams, sukauptos geležies pakanka pirmuosius keturis šešis gyvenimo mėnesius [34]. Remiantis Amerikos pediatru akademijos (AAP) rekomendacijomis, išnešiotiems, tik krūtimi maitinamiems kūdikiams, geleži reikètų pradèti vartoti nuo keturių mėnesių ( $1 \mathrm{mg} / \mathrm{kg}$ per dieną), kol bus pradètas maitinimas geležies turinčiu maistu $[3,4]$. Patarimai dèl mitybos yra labai svarbūs, todèl reikia paaiškinti, kad geležies, gaunamos iš mésos (raudonos arba baltos), biologinis prieinamumas yra didesnis. Be mèsos, vaikai turètų būti skatinami valgyti citrinas, daržoves ir ankštinius augalus, ispejjami vengti sodos, arbatos, kavos, per didelio pieno kie- 
kio ir javų, kurie mažina geležies absorbciją [31]. Pirminè geležies stokos prevencija geležies preparatais paaugliams nerekomenduojama, išskyrus atvejus, kai pasireiškia kiti sutrikimai, pvz. gausus menstruacinis ciklas [35]. Rekomenduojamas papildomos geležies suvartojimo kiekis vaikams pateikiamas 2 lentelèje $[3,4,36]$.

\section{Išvados}

1. Geležies stokos anemija yra dažna patologinè būklè, pasitaikanti kūdikiams, vaikams ir paaugliams.

2. Pagrindiniai kūdikių geležies stokos anemijos rizikos veiksniai yra motinos geležies stokos anemija néštumo metu bei ankstyvas virkštelès užspaudimas po gimimo; vaikų ir paaugliu - per mažas geležies gavimas su maistu, antsvoris, nutukimas, mergaičių menarchè ar kiti menstruacinio ciklo sutrikimai.

3. Geležies papildų vartojimas nèštumo metu padidina hemoglobino koncentraciją kraujyje ir žymiai sumažina naujagimių anemijos riziką, geležies deficitą ir mažo svorio naujagimio riziką.

4. Pavėlintas virkštelès užspaudimas ( $>3$ minutes) turi reikšmingą poveikį naujagimių geležies kiekiui ir turi įtakos geležies stokos anemijos pasireiškimui naujagimiams iki 4 mènesių.

5. Neišnešiotiems naujagimiams svarbu gauti papildomos geležies preparatų. Esant mitybos sutrikimų, svarbu paaiškinti, kad geležies, gaunamos iš mèsos (raudonos arba baltos), biologinis prieinamumas yra didesnis. Be mèsos, vaikai turètų būti skatinami valgyti citrinas, daržoves ir ankštinius augalus, įspejjami vengti sodos, arbatos, kavos, per didelio pieno kiekio ir javų, kurie mažina geležies absorbciją.

6. Pirminè geležies stokos prevencija geležies preparatais paaugliams nerekomenduojama, išskyrus atvejus, kai pasireiškia ir kiti sutrikimai, pvz. gausus menstruacinis ciklas.

\section{Literatūra}

1. World Health Organization. Worldwide prevalence of anaemia 1993-2005. 2008. http://whqlibdoc.who.int/publications/2008/9789241596657_eng.pdf.

2. De Andrade Cairo RC, Rodrigues Silva L, Carneiro Bustani N, Ferreira Marques CD. Iron deficiency anemia in adolescents; a literature review. Nutr Hosp 2014;29(6):1240-9.

3. Baker RD, Greer FR, Committee on Nutrition American Academy of Pediatrics. Diagnosis and prevention of iron deficiency and iron-deficiency anemia in infants and young children (0-3 years of age). Pediatrics 2010;126(5):1040-1050. https://doi.org/10.1542/peds.2010-2576

4. Flerlage J, Engorn B, eds. The Harriet Lane handbook: a manual for pediatric house officers. 20th ed. Philadelphia, Pa.: Saunder/ Elsevier; 2015:305.
5. Short MW, Domagalski JE. Iron deficiency anemia: evaluation and management. Am Fam Physician 2013;87(2):98-104.

6. Sun J, Zhang L, Cui J, Li S, Lu H, Zhang Y, Li H, Sun J, Baloch Z. Effect of dietary intervention treatment on children with iron deficiency anemia in China: a meta-analysis. Lipids Health Dis 2018;17(1):108. https://doi.org/10.1186/s12944-018-0749-x

7. Tezera R, Sahile Z, Yilma D, Misganaw E, Mulu E. Prevalence of anemia among school-age children in Ethiopia: a systematic review and meta-analysis. Syst Rev 2018;7(1):80.

https://doi.org/10.1186/s13643-018-0741-6

8. World Health Organization. The global prevalence of anaemia in 2011. http://apps.who.int/iris/bitstream/10665/177094/1/9789241564960_eng.pdf?ua=1.

9. Benoist BD, McLean E, Egll I, Cogswell M. Worldwide prevalence of anaemia 1993-2005: WHO global database on anaemia. Geneva: WHO global database on anaemia 2008.

10. Dalenius K, Borland E, Smith B, Polhamus B, Grummer-Strawn L. Centers for Disease Control and Prevention. Pediatric nutrition surveillance 2010 Report. 2012. http://www.cdc.gov/ pednss/pdfs/PedNSS_2010_Summary.pdf. Accessed October 27, 2015.

11. Lee JO, Lee JH, Ahn S, Kim JW, Chang H, Kim YJ, et al. Prevalence and risk factors for iron deficiency anemia in the Korean population: results of the fifth Korea national health and nutrition examination survey. J Korean Med Sci 2014; 29: 224-229.

https://doi.org/10.3346/jkms.2014.29.2.224

12. Abu-Ouf NM, Jan MM. The impact of maternal iron deficiency and iron deficiency anemia on child's health. Saudi Med J 2015;36(2):146-9.

https://doi.org/10.15537/smj.2015.2.10289

13. Domellof M, Dewey KG, Lnnerdal B, Cohen RJ, Hernell O. The diagnostic criteria for iron deficiency in infants should be reevaluated. J Nutr 2002;132(12):3680-6.

https://doi.org/10.1093/jn/132.12.3680

14. Miller JL. Iron deficiency anemia: a common and curable disease. Cold Spring Harb Perspect Med 2013;3(7):a011866. https://doi.org/10.1101/cshperspect.a011866

15. Oski F. Iron deficiency in infancy and childhood. N Engl J Med 1993; 329(3):190-193. https://doi.org/10.1056/NEJM199307153290308

16. Wang M. Iron deficiency and other types of anemia in infants and children. Am Fam Physician 2016;93(4):270-8.

17. Domellof M, Braegger C, Campoy C, Colomb V, Decsi T, et al. Iron requirements of infants and toddlers. J Pediatr Gastroenterol Nutr 2014;58(1):119-29.

https://doi.org/10.1097/MPG.0000000000000206

18. Lee AI, Okam MM. Anemia in pregnancy. Hematol Oncol Clin North Am 2011; 25: 241-259, vii.

https://doi.org/10.1016/j.hoc.2011.02.001

19. Black MM, Quigg AM, Hurley KM, Pepper MR. 2011. Iron 
deficiency and iron-deficiency anemia in the first two years of life: strategies to prevent loss of developmental potential. Nutr Rev 69:S64-S70.

https://doi.org/10.1111/j.1753-4887.2011.00435.x

20. Andersson O, Hellström-Westas L, Andersson D, Domellöf M. Effect of delayed versus early umbilical cord clamping on neonatal outcomes and iron status at 4 months: a randomised controlled trial. BMJ 2011;343:d7157. https://doi.org/10.1136/bmj.d7157

21. Mesías M, Seiquer I, Navarro MP. Iron nutrition in adolescence. Crit Rev Food Sci Nutr 2013;53(11):1226-37. https://doi.org/10.1080/10408398.2011.564333

22. Nead KG, Halterman JS, Kaczorowski JM, Auinger P, Weitzman M. Overweight children and adolescents: a risk group for iron deficiency. Pediatrics 2004;114(1): 104-8.

https://doi.org/10.1542/peds.114.1.104

23. Merckel D, Huerta M, Grotto I, Blum D, Tal O, Rachmilewitz E et al. Prevalence of iron deficiency and anemia among strenuously trained adolescents. J Adolesc Health 2005;37(3):220-3. https://doi.org/10.1016/j.jadohealth.2004.08.029

24. Hoffbrand AV, PAH Moss, Pettit JE. Fundamentos em hematologia. $5^{\mathrm{a}}$ ed. Artmed: São Paulo 2006.

25. Ballard L, Lyon DS, Jones JL. Patients with menometrorrhagia: etiologies, treatments, and outcomes. South Med J 2000;93(6):571-4.

https://doi.org/10.1097/00007611-200093060-00005

26. Rybo G, Leman J, Tibblin R. Epidemiology of menstrual blood loss. In: Baird DT, Michie EA, editors. Mechanisms of menstrual bleeding. New York: Raven Press 1985:181.

27. Michaca VJS, Galaviz JLG, Pasillas MV, Huerta SF, Martinez LB, Monroy JVO, et. al. Consenso nacional para el diagnóstico y tratamiento de la anemia em la infancia y em la adolescencia. Pediatria de México 2012;14(2):71-85.

28. Pinhas-Hamiel O, Newfield RS, Koren I, Agmon A, Lilos P, Phillip M. Greater prevalence of iron deficiency in overweight and obese children and adolescents. Int J Obes Relat Metab Di - sord 2003;27 (3):416-8.

https://doi.org/10.1038/sj.ijo.0802224

29. Santos CLA, Akerman M, Faccenda O, Martins LC, Reato LFN. Iron deficiency during pubertal growth spurt. Rev Bras Crescimento Desenvolv Hum 2012;22(3): 341-7.

https://doi.org/10.7322/jhgd.46611

30. Reeves JD, Yip R, Kiley VA, Dallman PR. Iron deficiency in infants: the influence of mild antecedent infection. J Pediatr 1984;105(6):874-9. https://doi.org/10.1016/S0022-3476(84)80069-4

31. Torres MA, Lobo NF, Sato K, Queiroz SS. Fortification of fluid milk for the prevention and treatment of iron deficiency anemia in children under 4 years of age. Rev Saude Publica 1996;30(4):350-7.

https://doi.org/10.1590/S0034-89101996000400008

32. Scholl TO. Maternal iron status: relation to fetal growth, length of gestation, and iron endowment of the neonate. Nutr Rev 2011;69(suppl 1):S23-S29.

https://doi.org/10.1111/j.1753-4887.2011.00429.x

33. Haider BA, Olofin I, Wang M, et all. Anaemia, prenatal iron use, and risk of adverse pregnancy outcomes: systematic review and meta-analysis. BMJ 2013;346:f3443.

https://doi.org/10.1136/bmj.f3443

34. Uijterschout L, Vloemans J, Rövekamp-Abels L, Feitsma H, van Goudoever JB, Brus F. The influences of factors associated with decreased iron supply to the fetus during pregnancy on iron status in healthy children aged 0.5 to 3 years. J Perinatol 2014;34(3):229-233

https://doi.org/10.1038/jp.2013.163

35. Yip R, Walsh KM, Goldfarb MG, Binkin NJ. Declining prevalence of anemia in childhood in a middle-class setting: a pediatric success story? Pediatrics 1987; 80 (3): 330-4.

36. Janus J, Moerschel SK. Evaluation of anemia in children. Am Fam Physician 2010;81(12):1462-1471

\section{IRON DEFICIENCY ANEMIA IN INFANTS AND CHILDREN AND ADOLESCENTS: RISK FACTORS AND PREVENTION \\ V. Zeleckytè, M. Zaremba, V. Ališkeviciūtè}

Keywords: iron deficiency anemia, infants, children, adolescents.

Summary

Iron deficiency anemia is a serious condition that often occurs in infants, children and adolescents. The higher risk in children is explained by the increased iron requirements due to rapid growth, increased lean body mass, red cell mass and blood levels, which increase the iron requirements for hemoglobin in the blood and myoglobin in the muscles. This paper analyzes scientific publications describing the most common risk factors for iron deficiency anemia. The main ones in infants are maternal iron deficiency anemia during pregnancy and early umbilical cord compression after birth, in children and adolescents - low iron intake with food, overweight or obesity and menarche or other menstrual disorders in girls. Publications have been found to demonstrate that the onset of this disease can be prevented by taking appropriate preventive factors. Summarizing the reviewed literature and scientific it was concluded that the use of iron supplements during pregnancy increases hemoglobin levels in the blood and significantly reduces the risk of neonatal anemia, iron deficiency and the risk of low birth weight. Delayed umbilical cord compression (> 3 minutes) has a significant effect on neonatal iron levels and also on the onset of iron deficiency anemia in neonates up to four months. Studies have shown that it is important for premature babies to receive supplemental iron supplements, while in the case of eating disorders it is important to explain that the bioavailability of iron from meat (red or white meat) is higher. In addition to meat, children should be encouraged to eat lemons, vegetables and legumes and warned to avoid soda, tea, coffee, excessive milk and cereals that reduce iron absorption. It has been found that primary prevention of iron deficiency with iron supplements is not recommended in adolescents unless other disorders occur, e.g. abundant menstrual cycle.

Correspondence to: vykinta.zeleckyte@gmail.com Gauta 2020-11-27 